\section{JURNAL EKONOMI EFEKTIF}

ISSN : $2622-8882$, E-ISSN : 2622-9935

Jurnal Ekonomi Efektif, Vol. 4, No. 1, Oktober 2021 @Prodi Manajemen Fakultas Ekonomi Universitas Pamulang

\title{
PENGARUH STORE ATMOSPHERE TERHADAP KEPUTUSAN PEMBELIAN PADA STARBUCKS DI JAKARTA
}

\author{
Haris Suganda Hidayat ${ }^{1}$, Nurlina ${ }^{2}$, Rahayu Kharismawaty ${ }^{3}$, Safta Wijaya ${ }^{4}$, \\ Ali Maddinsyah ${ }^{5^{*}}$ \\ Universitas Pamulang, Tangerang Selatan, Banten, Indonesia \\ harissuganda.h@gmail.com ${ }^{1}$, nlina.cac@gmail.com ${ }^{2}$, \\ rahayukharismawaty@gmail.com ${ }^{3}, \underline{\text { saptawijaya84@gmail.com }}$, \\ alimaddinsyah@unpam.ac.id ${ }^{5^{*}}$
}

Manuskrip: September -2021; Ditinjau: September: -2021; Diterima: September-2021; Online: Oktober-2021; Diterbitkan: Oktober-2021

\begin{abstract}
ABSTRAK
Penelitian ini bertujuan untuk mengetahui pengaruh Store Atmosphere terhadap keputusan pembelian pada Starbucks di Jakarta. Metode yang digunakan adalah explanatory research dengan sampel sebanyak 102 responden. Teknik analisis menggunakan analisis statistik dengan pengujian regresi, korelasi, determinasi dan uji hipotesis. Hasil penelitian ini variabel Store Atmosphere diperoleh nilai rata-rata skor sebesar 3,411 dengan kriteria baik. Variabel keputusan pembelian diperoleh nilai rata-rata skor sebesar 3,837 dengan kriteria baik. Store Atmosphere berpengaruh positif dan signifikan terhadap keputusan pembelian dengan nilai persamaan regresi $\mathrm{Y}=9,297+0,852 \mathrm{X}$, dan nilai koefisien korelasi 0,777 atau memiliki tingkat hubungan yang kuat dengan nilai determinasi $60,4 \%$. Uji hipotesis diperoleh signifikansi $0,000<0,05$.
\end{abstract}

Kata Kunci: Store Atmosphere, Keputusan Pembelian

\begin{abstract}
This study aims to determine the effect of Store Atmosphere on purchasing decisions at Starbucks in Jakarta. The method used is explanatory research with a sample of 102 respondents. The analysis technique uses statistical analysis with regression, correlation, determination and hypothesis testing. The results of this study the Store Atmosphere variable obtained an average score of 3,411 with good criteria. The purchase decision variable obtained an average score of 3.837 with good criteria. Store Atmosphere has a positive and significant effect on purchasing decisions with a regression equation value of $Y=9.297+$ $0.852 X$, and a correlation coefficient value of 0.777 or has a strong relationship with a determination value of $60.4 \%$. Hypothesis testing obtained a significance of $0.000<0.05$.
\end{abstract}

\section{Keywords: Store Atmosphere, Purchase Decision}




\section{PENDAHULUAN}

\section{A. Latar Belakang Masalah}

Kondisi persaingan dalam dunia bisnis menuntut setiap pengusaha untuk mampu bersaing dan bertahan melawan pesaing. Banyaknya perusahaan yang berlomba untuk mendapatkan konsumen menjadikan kondisi kompetisi antar perusahaan berlangsung semakin ketat. Persaingan yang sangat ketat menuntut para pengusaha untuk dapat menentukan strategi yang tepat dalam berkompetisi, yaitu dalam melakukan pemenuhan kebutuhan konsumen yang selalu bervariasi.

Ada berbagai macam bisnis yang bisa menjadi peluang usaha, salah satunya adalah bisnis cafe and resto. Saat ini sudah semakin banyak produsen cafe and resto yang terlibat dalam pemenuhan kebutuhan dan keinginan konsumen. Hal tersebut membuat pengusaha starbucks harus berupaya untuk memahami kebutuhan, keinginan, dan permintaan pasar sasaran. Pengusaha tersebut harus berupaya untuk mendapatkan perhatian serta ketertarikan khalayak ramai (dalam hal ini calon konsumen), karena mereka bersaing dengan perusahaan yang memiliki produk serupa. Maka dari itu setiap pengusaha dengan jenis produk serupa harus memikirkan cara untuk menangkan pasar.

Salah satu cara untuk memenangkan persaingan adalah dengan membuat sesuatu yang berbeda. Store atmosphere bisa menjadi alternatif untuk membedakan cafe yang satu dengan yang lainnya. Perbedaan diperlukan karena dari setiap bisnis pasti didapati produk yang serupa dengan harga yang berkisar beda tipis bahkan sama. Store atmosphere bisa menjadi alasan lebih bagi konsumen untuk tertarik dan memilih dimana ia akan berkunjung dan membeli. Hal ini seperti yang dikemukakan oleh Levy dan Weitz (2001:556) "Customer purchasing behavior is also influenced by the store atmosphere". Dalam keputusan pembelian, konsumen tidak hanya memberi respon terhadap barang dan jasa yang ditawarkan, tetapi juga memberikan respon terhadap lingkungan pembelian yang menyenangkan bagi konsumen. Hal ini membuat konsumen tersebut memilih toko, rumah makan, atau cafe yang disukai dan melakukan pembelian.

Membuat konsumen tertarik adalah salah satu tujuan awal dan selanjutnya pasti bertujuan untuk mendorong hasrat konsumen untuk membeli. Store atmosphere yang ditawarkan produsen, jika ditanggapi dengan positif oleh konsumen akan memperoleh peluang besar bagi tempat tersebut untuk dikunjungi.

Suasana yang mengacu pada desain dari lingkungan melalui komunikasi visual, pencahayaan, warna, musik, dan aroma yang merangsang pelanggan secara perseptual dan emosional serta pada akhirnya mempengaruhi perilaku pembelian mereka". Dapat diasumsikan bahwa penilaian atau tanggapan konsumen terhadap store atmosphere akan mempengaruhi pembelian konsumen. Salah satu yang menjadi pertimbangan dalam pengambilan keputusan pembelian adalah store atmosphere yang menarik.

Store atmosphere tidak hanya berpengaruh terhadap keputusan pembelian, tetapi juga berpengaruh terhadap kepuasan pelanggan. Meskipun semua faktor penentu kepuasan pelanggan perlu diperhatikan dalam penelitian dan praktek, untuk sebagian besar mungkin suasana menentukan tingkat keseluruhan kepuasan di industri restoran.

Store atmosphere merupakan kombinasi dari hal- hal yang bersifat emosional. Menurut Mowen dan Minor (2002:139) store atmosphere mempengaruhi keadaan emosional pembelanja, yang kemudian mendorong untuk meningkatkan atau mengurangi belanja. Dampak dari store atmosphere bisa menciptakan kesan yang membuat pembeli akan meningkatkan pembeliannya atau hanya membeli secukupnya dan kemungkinan tidak berniat kembali lagi untuk membeli di tempat tersebut.

Kesan yang diperoleh berdampak pada kepuasan pelanggan. Produsen harus jeli dalam melihat peluang pasar serta keinginan dan kebutuhan pelanggan agar mampu 
memberikan kepuasan pada pelanggan sehingga tidak beralih pada kompetitor. Bagaimana pun alat pendukung dari konsep pemasaran adalah identifikasi dan kepuasan dari kebutuhan pelanggan. Pelanggan yang puas akan terus melakukan pembelian pada starbucks tersebut, demikian pula sebaliknya.

Sejak merambah pasar Indonesia tahun 2002, jumlah kedai Starbucks terus meningkat. Anthony Cottan (2014) selaku Direktur PT. Sari Coffee Indonesia mengatakan daya beli masyarakat Indonesia terus meningkat sehingga mendorong Starbucks untuk terus menambah kedai baru, karena Indonesia merupakan pangsa pasar yang besar bagi Starbucks. Howard Schultz (2014) selaku CEO Starbucks Corporation, menyatakan bahwa pertumbuhan Starbucks di Asia sangat pesat, terutama di Indonesia.

Subyek dari penelitian ini adalah Monopoli starbucks. Monopoli adalah salah satu starbucks di kota Jakarta yang memiliki konsep sangat unik, dengan nama tempat mengambil dari nama permainan anak-anak yaitu Monopoli Starbucks. Starbucks ini menarik untuk diteliti karena memiliki konsep store atmosphere yang menarik dengan mengusung konsep view indoor dan outdoor.

Berdasarkan pemaparan pada latar belakang masalah di atas, maka penulis tertarik melakukan penelitian lebih lanjut dengan judul "Pengaruh Store Atmosphere Terhadap Keputusan Pembelian Konsumen Pada Starbucks di Jakarta".

\section{B. Rumusan Masalah}

1. Bagaimana Store Atmosphere pada Starbucks di Jakarta?.

2. Bagaimana keputusan pembelian pada Starbucks di Jakarta?.

3. Adakah pengaruh antara Store Atmosphere terhadap keputusan pembelian pada Starbucks di Jakarta?.

\section{Tujuan Penelitian}

1. Untuk mengetahui kondisi Store Atmosphere pada Starbucks di Jakarta.

2. Untuk mengetahui kondisi keputusan pembelian pada Starbucks di Jakarta.

3. Untuk mengetahui pengaruh Store Atmosphere terhadap keputusan pembelian pada Starbucks di Jakarta.

\section{TINJAUAN PUSTAKA}

\section{Store atmosphere}

Store Atmosphere merupakan salah satu hal yang penting terutama dalam perusahaan penyedia jasa, karena kenyamanan konsumen merupakan hal yang perlu di utamankan. Dalam hal ini menurut Bermen dan Even (2019:528), "suasana toko meliputi berbagai tampilan interior, eksterior, tata letak, lalu lintas toko, kenyamanan, udara, layanan, music, seragam, penjagaan barang dan sebagainya yang menimbulkaan daya Tarik bagi konsumen dan membangkitkan keinginan untuk membeli”.

\section{Keputusan Pembelian}

Menurut Kotler dan Amstrong (2019) berpendapat "perilaku konsumen merupakan sebuah pendekatan penyesuaian masalah yang terdiri dari lima tahap yang dilakukan konsumen. Kelima tahap tersebut adalah pengenalan masalah, pencarian informasi, evaluasi alternatif, keputusan pembelian, dan perilaku pasca pembelian”.

\section{METODE PENELITIAN}

\section{Populasi}

Populasi dalam penelitian ini berjumlah 102 responden Starbucks di Jakarta 


\section{Sampel}

Teknik pengambilan sampling dalam penelitian ini adalah sampel jenuh, dimana semua anggota populasi dijadikan sebagai sampel. Dengan demikian sampel dalam penelitian ini sampel yang digunakan berjumlah 102 responden.

\section{Jenis Penelitian}

Jenis penelitian yang dipakai adalah asosiatif, dimana tujuannya adalah untuk mengetahui atau mencari keterhubungan antara variabel independen terhadap variabel dependennya

\section{Metode Analisis Data}

Dalam menganalisis data digunakan uji validitas, uji reliabilitas, analisis regresi linier sederhana, analisis koefisien korelasi, analisis koefisien determinasi dan pengujian hipotesis.

\section{HASIL PENELITIAN}

\section{Analisis Deskriptif}

Pada pengujian ini digunakan untuk mengetahui skor minimum dan maksimum skor tertinggi, ratting score dan standar deviasi dari masing-masing variabel. Adapun hasilnya sebagai berikut:

Tabel 1. Hasil Analisis Descriptive Statistics

Descriptive Statistics

\begin{tabular}{ll|r|r|r|r} 
& N & Minimum & Maximum & Mean & Std. Deviation \\
\hline Store Atmosphere (X) & 102 & 28 & 44 & 34.11 & 3.833 \\
\hline Keputusan Pembelian (Y) & 102 & 29 & 49 & 38.37 & 4.205 \\
\hline Valid N (listwise) & 102 & & & & \\
\hline
\end{tabular}

Store Atmosphere diperoleh varians minimum sebesar 28 dan varians maximum 44 dengan ratting score sebesar 3,411 dengan standar deviasi 3,833. Skor ini termasuk pada rentang sakala 3,40-4,19 dengan kriteria baik atau setuju.

Keputusan pembelian diperoleh varians minimum sebesar 29 dan varians maximum 49 dengan ratting score sebesar 3,837 dengan standar deviasi 4,205. Skor ini termasuk pada rentang sakala 3,40 - 4,19 dengan kriteria baik atau setuju.

\section{Analisis Kuantitatif}

Pada analisis ini dimaksudkan untuk mengetahui pengaruh variabel independen terhadap variabel dependen. Adapun hasil pengujian sebagai berikut:

\section{a. Analisis Regresi Linier Sederhana}

Uji regresi ini dimaksudkan untuk mengetahui perubahan variabel dependen jika variabel independen mengalami perubahan. Adapun hasil pengujiannya sebagai berikut:

\begin{tabular}{|c|c|c|c|c|c|}
\hline \multirow[b]{3}{*}{ Model } & \multicolumn{2}{|c|}{ Coefficients ${ }^{\mathrm{a}}$} & \multirow{3}{*}{$\begin{array}{c}\text { Standardized } \\
\text { Coefficients } \\
\text { Beta } \\
\end{array}$} & \multirow[b]{3}{*}{$\mathrm{t}$} & \multirow[b]{3}{*}{ Sig. } \\
\hline & \multicolumn{2}{|c|}{$\begin{array}{l}\text { Unstandardized } \\
\text { Coefficients }\end{array}$} & & & \\
\hline & B & Std. Error & & & \\
\hline 1 (Constant) & 9.297 & 2.370 & & 3.923 & .000 \\
\hline Store Atmosphere (X) & .852 & .069 & .777 & 12.345 & .000 \\
\hline
\end{tabular}

Berdasarkan hasil pengujian pada tabel di atas, diperoleh persamaan regresi $\mathrm{Y}$ $=9,297+0,852 X$. Dari persamaan tersebut dijelaskan sebagai berikut:

1) Konstanta sebesar 9,297 diartikan jika Store Atmosphere tidak ada, maka telah terdapat nilai keputusan pembelian sebesar 9,297 point. 
2) Koefisien regresi Store Atmosphere sebesar 0,852, angka ini positif artinya setiap ada peningkatan Store Atmosphere sebesar 0,852 point maka keputusan pembelian juga akan mengalami peningkatan sebesar 0,852 point.

\section{b. Analisis Koefisien Korelasi}

Analisis koefisien korelasi dimaksudkan untuk mengetahui tingkat kekuatan hubungan dari variabel independen terhadap variabel dependen. Adapun hasil pengujian sebagai berikut:

Tabel 3. Hasil Pengujian Koefisien Korelasi Store Atmosphere Terhadap Keputusan Pembelian.

Correlations $^{\text {b }}$

\begin{tabular}{|c|c|c|c|}
\hline & & $\begin{array}{c}\text { Store } \\
\text { Atmosphere }(\mathrm{X} 1)\end{array}$ & $\begin{array}{c}\text { Keputusan } \\
\text { Pembelian (Y) }\end{array}$ \\
\hline \multirow[t]{2}{*}{ Store Atmosphere (X) } & Pearson Correlation & 1 & $.777^{* *}$ \\
\hline & Sig. (2-tailed) & & .000. \\
\hline \multirow[t]{2}{*}{ Keputusan Pembelian (Y) } & Pearson Correlation & $.777^{* *}$ & 1 \\
\hline & Sig. (2-tailed) & .000 & \\
\hline
\end{tabular}

Berdasarkan hasil pengujian diperoleh nilai korelasi sebesar 0,777 artinya Store Atmosphere memiliki hubungan yang kuat terhadap keputusan pembelian.

\section{c. Analisis Koefisien Determinasi}

Analisis koefisien determinasi dimaksudkan untuk mengetahui besarnya persentase pengaruh dari variabel independen terhadap variabel dependen. Adapun hasil pengujian sebagai berikut:

Tabel 4. Hasil Pengujian Koefisien Determinasi Store Atmosphere Terhadap Keputusan Pembelian.

Model Summary

\begin{tabular}{ll|l|r|r} 
& & \multicolumn{2}{c}{} & \multicolumn{2}{c}{$\begin{array}{c}\text { Adjusted R } \\
\text { Model }\end{array}$} & $\mathrm{R}$ & R Square & \multicolumn{2}{c}{$\begin{array}{c}\text { Std. Error of the } \\
\text { Estimate }\end{array}$} \\
\hline 1 & $.777^{\mathrm{a}}$ & .604 & .600 & 2.660 \\
\hline
\end{tabular}

Berdasarkan hasil pengujian diperoleh nilai determinasi sebesar 0,604 artinya Store Atmosphere memiliki kontribusi pengaruh sebesar 60,4\% terhadap keputusan pembelian, sedangkan sisanya sebesar 39,4\% dipengaruhi oleh faktor lain yang tidak dilakukan penelitian.

\section{d. Uji Hipotesis}

Pengujian hipotesis dengan uji t digunakan untuk mengetahui hipotesis mana yang diterima.

Rumusan hipotesis: Terdapat pengaruh yang signifikan Store Atmosphere terhadap keputusan pembelian.

Tabel 5. Hasil Uji Hipotesis Store Atmosphere Terhadap Keputusan Pembelian.

\begin{tabular}{|c|c|c|c|c|c|}
\hline \multirow[b]{2}{*}{ Model } & \multicolumn{2}{|c|}{$\begin{array}{c}\text { Coefficients }^{\mathbf{a}} \\
\text { Unstandardized } \\
\text { Coefficients }\end{array}$} & \multirow{2}{*}{$\begin{array}{c}\text { Standardized } \\
\text { Coefficients } \\
\text { Beta }\end{array}$} & \multirow[b]{2}{*}{$\mathrm{t}$} & \multirow[b]{2}{*}{ Sig. } \\
\hline & $\mathrm{B}$ & Std. Error & & & \\
\hline 1 (Constant) & 9.297 & 2.370 & & 3.923 & .000 \\
\hline Store Atmosphere (X) & .852 & .069 & .777 & 12.345 & .000 \\
\hline
\end{tabular}

Berdasarkan hasil pengujian pada tabel di atas, diperoleh nilai t hitung $>\mathrm{t}$ tabel atau $(7,809>1,984)$, dengan demikian hipotesis yang diajukan bahwa terdapat 
pengaruh yang signifikan atara Store Atmosphere terhadap keputusan pembelian diterima.

\section{Pembahasan Hasil Penelitian}

\section{Kondisi Jawaban Responden Variabel Store Atmosphere}

Berdasarkan jawaban responden, variabel Store Atmosphere diperoleh ratting score sebesar 3,411 berada di rentang skala 3,40 - 4,19 dengan kriteria baik atau setuju.

\section{Kondisi Jawaban Responden Variabel Keputusan Pembelian}

Berdasarkan jawaban responden, variabel keputusan pembelian diperoleh ratting score sebesar 3,837 berada di rentang skala 3,40 - 4,19 dengan kriteria baik atau setuju.

\section{Pengaruh Store Atmosphere Terhadap Keputusan Pembelian}

Store Atmosphere berpengaruh signifikan terhadap keputusan pembelian dengan persamaan regresi $\mathrm{Y}=9,297+0,852 \mathrm{X}$, nilai korelasi sebesar 0,777 atau memiliki hubungan yang kuat dengan kontribusi pengaruh sebesar 60,4\%. Pengujian hipotesis diperoleh nilai t hitung $>\mathrm{t}$ tabel atau $(7,809>1,984)$. Dengan demikian hipotesis yang diajukan bahwa terdapat berpengaruh signifikan antara Store Atmosphere terhadap keputusan pembelian diterima.

\section{KESIMPULAN DAN SARAN}

\section{Kesimpulan}

a. Variabel Store Atmosphere diperoleh ratting score sebesar 3,411 berada di rentang skala 3,40-4,19 dengan kriteria baik atau setuju.

b. Variabel keputusan pembelian diperoleh ratting score sebesar 3,837 berada di rentang skala 3,40 - 4,19 dengan kriteria baik atau setuju.

c. Store Atmosphere berpengaruh signifikan terhadap keputusan pembelian dengan persamaan regresi $\mathrm{Y}=9,297+0,852 \mathrm{X}$, nilai korelasi sebesar 0,777 atau kuat dan kontribusi pengaruh sebesar 60,4\% sedangkan sisanya sebesar 39,4\% dipengaruhi faktor lain. Uji hipotesis diperoleh nilai t hitung > t tabel atau $(7,809>1,984)$.

\section{Saran}

Berdasarkan hasil penelitian di atas, maka penulis memberikan saran sebagai berikut:

a. Saat ini konsumen maupun pelanggan lebih kritis dalam memutuskan suatu keputusan pembelian. Hal ini dikarenakan sudah banyak starbucks mulai banyak bermunculan dengan penawaran serupa. Maka sebaiknya sebuah Cafe and Resto harus memiliki ciri khas tertentu. Jika sudah berhasil memenangkan hati konsumen, selalu melakukan evaluasi dan perbaikan juga terus kreatif untuk mengembangkan penawaran yang sudah ada.

b. Sebagian besar pelanggan memutuskan membeli di Monopoli Starbucks karena store atmosphere-nya, maka sudah seharusnya Monopoli menjaga keunggulan store atmosphere yang dimiliki, menerima dan memperbaiki apa yang menjadi masukan dari konsumen atau pelanggan.

c. Kepuasan memang bukan merupakan tujuan utama dari penciptaan store atmosphere, namun jika store atmosphere tersebut dapat memberikan kepuasan dibenak konsumen maka akan berdampak besar pada pembelian. 


\section{DAFTAR PUSTAKA}

Algifari. (2015). "Analisis Regresi untuk Bisnis dan Ekonomi”. Yogyakarta: BPFE.

Arikunto, Suharsimi (2014). "Prosedur Penelitian Suatu Pendekatan Praktek”. Wilayah Cianjur: Rineka Cipta.

Asih, P. S., et al. 2021). Analisis Faktor-Faktor Yang Mempengaruhi Keputusan Pembelian Produk Fastfood KFC Di Kota Sorong (Studi Kasus Mega Mall Kota Sorong). Jurnal Ilmiah PERKUSI, 1(3), 352-356.

Basu Swastha Dharmmesta. (2014). Manajemen Pemasaran. BPFE: Yogyakarta. Buchari Alma. 2014. Manajemen pemasaran dan Pemasaran Jasa. Edisi Revisi.

Bilson Simamora (2016) Panduan Riset Prilaku Konsumen, Wilayah Cianjur: PT. Gramedia Pustaka.

Erlangga, H., et al.(2021). Pengaruh Kualitas Pelayanan Dan Kualitas Produk Terhadap Keputusan Pembelian Konsumen Sepeda Motor Honda Di PT Panca Sakti Perkasa Di Bintaro. Jurnal Ilmiah PERKUSI, 1(4), 464-472.

Fandy Tjiptono (2017), Serivce Quality and Satisfiation. Wilayah Cianjur: Edisi tiga. Andi.

Freddy Rangkuti (2016) Strategi Promosi Yang Kreatif, Edisi Pertama, Cetakan Pertama Wilayah Cianjur: Gramedia Pustaka Utama.

Imam Ghozali (2017). "Aplikasi Analisis Multivariate Dengan Program SPSS”. Edisi Kelima. Semarang: Badan Penerbit Undip.

Istijanto (2014) "Riset Sumber Daya Manusia”. Wilayah Cianjur: PT. Gramedia Pustaka Kharis, Ismu Fadli (2011). "Studi Mengenai Impulse Buying dalam Penjualan Online”. Semarang : Skripsi Universitas Diponegoro

Kotler dan Amstrong (2017), Prinsip-prinsip Pemasaran. Edisi Kedua Belas”. Jilid Satu. Wilayah Cianjur: Erlangga.

Lupiyoadi (2016) Manajemen Pemasaran Jasa, Edisi 4, Wilayah Cianjur: Salemba Empat. Maddinsyah, A., et al. (2020). Desain Formulasi Dan Implementasi Bisnis Strategik Dengan Pendekatan Business Model Canvas (BMC) Terintegrasi Kerangka Integrated Performance Management System (IPMS) Pada Koperasi Asperindo. Inovasi, 7(2), 67-76.

Mani, J. (2017). Pengaruh Persepsi Merek Dan Store atmosphere Terhadap Kepuasan Pelanggan (Studi Kasus Pada PT. Bisma Narendra Di Wilayah Cianjur). Jurnal Mandiri, 1(2), 187-206.

Nurjaya, N., et al. (2021). Pengaruh Brand Image Terhadap Keputusan Pembelian Pada PT. Wahana Motor Di Wilayah Cianjur. Jurnal Ilmiah PERKUSI, 1(2), 291-296.

Phipil Kotler dan Kevin Keller (2017) Manajemen Pemasaran, Edisi Kedua Belas, Jilid Satu, Wilayah Cianjur: Erlangga.

Rao, Purba, (2012). "Measuring Consumer Perceptions Through Factor Analysis”, The Asian.

Rofianto, W., et al. (2021). Cultural Product Branding, Antecedents, And Its Implications:

A Study On The Context Of Indonesian Batik. International Journal Of Social, Policy And Law, 2(2), 37-46.

Santoso, Singgih (2015). "Menguasai Statistik Multivariat”. Wilayah Cianjur: PT Elex Media Komputindo.

Sudjana (2014) “Metode Statistika”, Bandung: Tarsido.

Sugiyono (2017), "Metode Penelitian Administrasi : dilengkapi dengan Metode $R \&$ D”. Bandung: Alfabeta.

Suhartanto (2014). “Metode Riset Pemasaran”. Bandung: Alfabeta. 